\title{
Editors, authors, and reviewers: Let's play frescobol?
}

\author{
Ph.D. Hélio ARthur Reis IRIgaray ${ }^{1}$ \\ ${ }^{1}$ Fundação Getulio Vargas (FGV EBAPE) / Brazilian SChool of Public ANd Business Administration, Rio de JaneIRO - RJ, BRAZIL
}

The editorial of this special issue is dedicated to readers, authors, and reviewers. You are this journal. You are Cadernos EBAPE.BR. We thank you for this partnership and hope that we can continue working together.

I would like to take this opportunity to share some thoughts on the stages of submission, evaluation, and publication (or not) of an article. Altogether, it is a complex process that is time-consuming, distressing, and, in the end, can be frustrating or pleasant for all parties involved.

As editor-in-chief, I implemented a system of continuous desk review to offer authors a quick first response. I also work to be closer to the authors establishing direct and more personal communication. Likewise, I am available to resolve any doubts that may persist; because it is the editor's job to ensure the publishing process's smoothness and transparency.

After this step, each submitted manuscript is sent to two voluntary reviewers, who separately recommend its approval, adjustments, or rejection. When there is no consensus between the reviewers, a third evaluates the manuscript to reach a final opinion - which can take more time.

Unfortunately, the relationship between authors and reviewers is not always harmonious. Sometimes it is marked by uncomfortable comments and mistrust. Therefore, we must never forget that we are members of the same community. Our main goal is to contribute to advance academic discussions benefitting our organizations and society.

Editors, reviewers, and authors cannot engage in a dispute where there are winners and losers. Hence, this is an invitation for us to play frescobol in a healthy relationship.

Frescobol is a sport created on the beaches of Rio de Janeiro. It is a two-player collaborative game, similar to beach tennis. It is a sport that cultivates friendship and commitment between players, without winners or losers. Frescobol is a metaphor that reflects our hope for a healthier academic environment.

The hope that Kierkegaard (1989) defined as "passion for the possible" updates our dreams and ability to project the future (RICOEUR, 1969) among the illusions of modernity and the disappointments of postmodernity.

We are like the youth described by Arendt (1994). We currently live with the colossal insecurity of potentially not having a future. Yet, we cannot give up our ideals.

These ideals are reflected in all the articles published in this issue.

In the first article, Gazi Islam - the newest member of our Editorial Board - and Neha Chatwani discuss how a single logic is maintained through heterogeneous acts and practices based on a strong identification with the logic of humanitarianism, in "The Humanitarian identifications: heterogeneous responses to institutional complexity at Médecins Sans Frontières".

In "The discretionary use of oil revenues in Brazil: Federal dynamics", Beni Trojbicz and Catarina lanni Segatto analyze the Brazilian case of federal centralization of oil revenues and show how jurisdictional preferences can guide federal dynamics through central federative mechanisms. 
In their article, "Social innovation living labs and public action: an analytical framework and a methodological route based on pragmatism", Thiago Magalhães, Carolina Andion, and Graziela Dias Alperstedt propose an analytical approach and a methodological route to understand the processes of collective learning, co-construction, and diffusion of knowledge in social innovation ecosystems, which is put into practice through social innovation living laboratories.

In "Transparency and accountability of government algorithms: the case of the Brazilian electronic voting system", Douglas Morgan Fullin Saldanha and Marcela Barbosa da Silva present a case study to identify the Brazilian electronic voting system's characteristics regarding transparency and accountability.

In the study, "Interorganizational knowledge transfer mechanisms: a study in the largest Brazilian institution of agricultural research", Daniela Martins Diniz, Fabricio Molica de Mendonça, Fátima Bayma de Oliveira, and Anderson de Souza Sant'Anna, analyze, from the theoretical perspective of interorganizational knowledge transfer, the role of these mechanisms in the performance of knowledge transfer between a Brazilian public research institution and its licensed companies.

"Gamification in organizations: learning processes and meaning-making", by Soraia Finamor Neidenbach, Vanessa Martines Cepellos, and Jussara Jéssica Pereira, discusses how learning processes and meaning-making through gamification are perceived as an organizational tool. The study is based on thematic analysis and reports from six experts in the field.

Maria Tereza Tomé de Godoy and Helenides Mendonça analyze the role of transformational leadership in adaptive competence. Their research, "Adaptive Expertise: A study on the influence of self-determination and transformational leadership", also tests the mediating role of self-determination in this relationship by satisfying the psychological needs of autonomy, belonging, competence, and achievement.

"Mobilities in the Labyrinth: pressuring the boundaries of women's careers", by Aline Mendonça Fraga and Sidinei Rocha-deOliveira, is a theoretical essay in which the authors discusses women's reduced opportunities of geographic and social mobility due to boundaries that engender immobility, anchored by sociocultural, political, organizational, and biological relations.

In their ethnographic study, "Exclusionary inclusion and inclusive exclusion: studies on harassment at a members club", Fernando Ressetti Pinheiro Marques Vianna, Francis Kanashiro Meneghetti, Juliana Previatto Baltini Tonon, and Leonardo Tonon analyze how and why marginalized populations are socially excluded from certain situations and included in others.

In, "Experience marketing: a study of the conceptual aspects", Maria Teresa Grimaldi Larocca, Rodrigo Ladeira, Áurio Lúcio Leocádio da Silva, and Ricardo Coutinho Mello review the evolution and current concepts of experience marketing according to the main scholars in this field.

Laís Rodrigues and Marcus Wilcox Hemais analyze, from a decolonial perspective, imperialist historical processes that enabled the incorporation of the Eurocentric self-regulation model in the creation of the Brazilian Advertising Self-Regulation System, SBAP, in their article entitled, "Eurocentric influences on the Brazilian Advertising Self-Regulation System: historical research from a decolonial perspective".

Under the same Weltanschauung, "Sweet \& sour: postcolonial professional kitchens in the postmodernity", by Carlos Henrique Gonçalves Freitas, Cíntia Rodrigues, and Valdir Machado Valadão Junior, exposes instances of inequality replicated in the kitchens of fine restaurants in the city of Uberlândia, Brazil.

In the article, "The limits of reason: deliberation and phronesis of correctional officers", Déris Oliveira Caitano and Maurício Serva examine the experience of prison officers in a maximum-security prison complex, observing elements that evidence phronesis.

Fabio José Ferraz and Denio Munia Benfatti present urban partnership operations (OUC) as public-private alliances that generate public value developed in a context of globalization and financialization of the real estate market, fiscal constraints, and primacy of private interests in the production of urban space, in "Additional building rights certificates: a funding mechanism for urban partnership operations or a speculative instrument?". 
"Competence as an ideological representation of the railroad surrounding the United States: a historiography between 1859 and 1869", is the research by Alexandre Hochmann Béhar and Marcos Gilson G. Feitosa. The authors analyze the ideological approaches to dimensions associated with competition in the US rail environment between 1859 and 1869.

I wish you a pleasant read.

Hélio Arthur Reis Irigaray

Editor-in-chief 


\section{REFERENCES}

ARENDT, H. Some Questions of Moral Philosophy. Social Research, v. 61, n. 4, p. 739-764, 1994. Available at: <http://www.jstor.org/ stable/40971058>. Acessed on: 05 nov. 2020.

RICOEUR, P. Guilt, Ethics and Religion. Royal Institute of Philosophy Lectures, n. 2, p. 100-117, 1968. Available at: <http://doi.org/10.1017/ S0080443600010918>. Acessed on: 05 nov. 2020.

KIERKEGAARD, S. The Concept of Anxiety: a simple psychologically orienting deliberation on the dogmatic issue of hereditary sin. Princeton: Princeton University Press, 1989.

Ph.D. Hélio Arthur Reis Irigaray

ORCID: https://orcid.org/0000-0001-9580-7859

Ph.D. from FGV EAESP; Master's in business administration from PUC-Rio; Bachelor degree in economics from the University of Northern lowa, USA;Adjunct professor at FGV EBAPE and the Corporate International Master Program (CIM), Georgetown University, Washington, USA; Leader of thetheme 'diversity and labor relations' in the line of research 'work management' (ANPAD). E-mail: helio.irigaray@fgv.br 